\title{
Structuralism and myth in Minoan studies
}

\author{
JOHN L. BINTLIFF
}

\begin{abstract}
Fohn Bintliff writes to us: 'If we archaeologists cannot honestly support the conscious rôle of social pedagogue, perhaps more fruitfully we may turn to the competing subjectivities of archaeological interpretation to seek insights into ourselves and our own age.' This article is an attempt to analyse archaeological interpretations of the bronze age Minoan society for such insights. Dr Bintliff is a Lecturer in the School of Archaeological Sciences, Bradford University, Yorkshire. He further asserts that this article is 'a very long gestation from your [the Editor's] own courses at Cambridge, 1968-71, in the history of archaeology!'
\end{abstract}

Nick Humphrey, of King's College, Cambridge, in a recent broadcast on Human Evolution, made the following comments (slightly paraphrased from my notes of the radio broadcast): 'Man, in comparison to the chimp is a forgetful ape. Chimps in experiments have a remarkable visual memory, recalling for example 25 complex patterns. Some humans can do the same, but rarely, and often where there is a brain malfunction as with epilepsy or damage to the parietal lobes. In effect it is characteristically pathological. Why was this facility suppressed? In order to replace this means of storing knowledge with a new way of thought. Not one of counting objects or observations as particular, but instead ordering such data into general models of things and situations, as with the Platonic Ideal forms. This was the birth of symbolic thought.'

I would now like to develop this theme further. In this shift from empirical accumulation to controlled comparison and cataloguing, the goal of the symbolizing mind to reduce novelty to order must lead inevitably to oversimplification. Moreover, the desire for a smooth functioning of everyday social and emotional life tends to call forth a set of basic categories to define other people, one's relationship to them, and to define activities and aims. It is here that the more specific sense of Structuralism appears, where the vast mass of experience that one meets is conquered by the operation of a set of cataloguing principles, whereby one can coordinate one's path amidst the world and its infinite units of animate and inanimate objects.
Ian Hodder, as the acknowledged leader of 'Structuralist Archaeology', has recently raised the stimulating issue of the neglect by archaeologists of this symbolic filter in their interpretation of past societies. For example, a collection of animal bones of a particular species from an archaeological site, need not represent valid evidence for its local dominance in the economy, since the culture concerned may utilize the differential disposal of bones from separate species to emphasize certain belief structures shared by the community.

Whilst pointing out that I do support the general principle of seeking to identify the symbolic filter in activity debris and physical structures uncovered by the archaeologist, we must also take account, first and foremost, of the constraints on our overall interpretations imposed by the nature of the archaeological record: namely, that we have at any one point in time a highly biased palimpsest of the past. Of course we are continually pushing back our knowledge in matters of detail, and the advent of hypothesis-testing as a principle (though hardly yet in practice!) will doubtless improve the consistency of our performance in shedding light on aspects of the past previously considered unapproachable by archaeology. Nonetheless I don't think I am preaching to the unconverted when I claim that there will almost certainly always be a gap in our knowledge, preventing us from drawing definitive conclusions as to the nature of past ideologies, political authority, social interactions of other kinds, and further complex aspects of early societies. 
For the still unconverted may I offer a chastening illustration of this truism. Recently an award for Amateur Archaeology in Britain was given to a study of World War II invasion defences or 'pillboxes' (Wills, 1979). The amateur archaeologist concerned was worried that so many were being destroyed, and wished to record them for posterity. You might think that a series of standing monuments of the r 940 s would best be approached via official records. But it soon became apparent that only the most general directive survives ordering local authorities to see to their defences. At a district level civil defence groups set to work, in ways unrecorded in official files, erecting a system of these concrete keeps and their associated lines of anti-tank pyramids. The essential task of the archaeologist was to plan all surviving units of such systems in each area, with the assistance of a host of present-day local informants, then to interpret for himself, on the basis of detailed local maps and locational inferences, what specific strategy had been intended for the defence of each segment of landscape. The same general point has been stressed in recent discussions of the art of dramatized reconstructions of history ('faction') in the media, such as the BBC television series on the life of Charles Darwin, where the deficiencies of the sources required imaginative leaps to complete a coherent narrative, even for this well-documented period and career (Ralling, i 980).

As archaeologists then, we shall have to continue in the foreseeable future, as in the past, to bridge that gap between what the data permit us to infer as strict scientists, and what we would like to be able to pronounce on as historians or 'social analysts'. We do this by the use of Models or generalizations about what we think is going on. These models tend however to become somewhat rigid from scholar to scholar. It is my belief and experience that it is not only worthwhile, but indeed necessary, to view the major theories and interpretations of scholars producing general syntheses from archaeological data, in the context of their authors' social and educational background, and philosophical and emotional stances-for possible elucidation of repetitive themes in their work. To take an obvious example, scholars of my generation have frequently drawn attention to a potential $\mathrm{PhD}$ topic in comparing the political speeches and known sympathies of Professor Colin Renfrew, with the stress in his archaeological writings on competitive elites and private-enterprise entrepreneurs as stimuli to socie- tal advance. The study of Gordon Childe's archaeological theories in the context of his Socialist beliefs has demonstrated very important interactions between a personal stance and the interpretation of ambiguous pre-historic data, as Peter Gathercole has shown (Gathercole, 1971).

To stand Structuralist Archaeology on its head, it may be necessary therefore not only to investigate patterning in the archaeological record, with a view to obtaining evidence of symbolic structures in past behaviour, but also to study the patterns inferred by the archaeologist in terms of the symbols and structures he wishes to identify in the rarely clear-cut archaeological record. When I hear, for instance, that a Structuralist study has been conceived, in order to compare and contrast the King's and the Queen's Apartments in Minoan palaces, I am very conscious that the initial structure of 'King' versus 'Queen' is a hypothetical distinction from mute groundplans, originating primarily in a set of semi-myths about Minoan society-a wished-for structure imposed long ago upon the excavated data. The raw truth about the strength of the evidence identifying Minoan rulers can be revealed by quoting from Gerald Cadogan: 'I am much less certain that the rulers of Minoan Crete until $145^{\circ}$ were men, whether kings, priests or gods, or any or all combined, rather than women.' He also suggests that the key Priest-King Fresco might be a woman and a priestess! (Cadogan, I976, 9 and 54 ).

Let us take this approach and apply it in a brief discussion of the social and historical context of Minoan archaeology.

In terms of the general history of Archaeology we can broadly categorize the nineteenth century as an era of 'stages'. Human development as revealed by the nascent discipline was to be set into the framework of the consecutive great ages of Stone and Metal, and their detailed subdivisions, which were correlated in their turn with distinct forms of social structure that had been derived from a hazy ethnography and a mixture of historical and mythical sources. The broad belief in the primacy of the tracing of 'stages' reflected the optimistic mood of 'Progress' towards the affluent industrial society of Victorian Western Europe, a path which imperialism was meant to hasten and history to underline. By the end of the century the individual features of local cultures were being recognized, allowing distinct culture histories to be written, and setting the broad approach for much of this century (i.e. that of Culture History, as described and 
condemned by Lewis Binford, I968). The History and Classics training of most archaeological 'synthesizers' within this tradition has combined with personal belief structures to influence the kind of historical events and forms of society which they have claimed to recognize in the archaeological data. Details of how societies worked and what ideologies were held have been obtained from analogy with other, better-documented societies and by the process of 'empathy' whereby one ponders on the data until an insight appears into the mind of early man (as Jacquetta Hawkes, $198 \mathrm{r}$, has recently described for us).

However, although 'stages' and 'Social Evolution' have remained central to historical and archaeological studies until quite recently, the original associated dogma that political and technological complexity was a direct reflexion of a desirable level of 'Progress' or 'Advancement' in a society, experienced a sharp decline from the latter part of the last century. This mirrored a growing awareness within intellectual life as a whole of the social and spiritual inadequacies of Western industrial society (familiar to us today from the novels of the Realist School, and the penetrating art of Degas, Toulouse-Lautrec, and the later PostImpressionists). In literary and artistic life an attempt to flee from these disturbing realities is seen in the sunset gaiety of the end of the century with its escapist overtones (as with the literally and spiritually superficial art of the Impressionists and Art Nouveau, or the literary atmosphere of the 'Naughty Nineties'), and especially in attempts such as that of Gauguin to flee to a supposed pre-Industrial paradise, in order to recapture the Earth's lost youth and innocence. J. H. Plumb has written of the early decades of the present century: 'If the belief of a man of [H. G.] Wells's passionate and intelligent humanism could be so battered and undermined, it is not surprising that lesser men were unable to withstand the climate of despair that engulfed the Western world ... The disillusion of these years is apparent in painting, in music, in literature, everywhere in the Western world we are brought up sharply by an expression of anguish, by the flight from social and historical reality into a frightened, self-absorbed world of personal feeling and expression. Intellectual life, outside science, has pursued much the same course as artistic life' (Plumb, 1971, xii-xiv).

Into this context I believe it appropriate to set the voyage of intellectual discovery charted by Sir
Arthur Evans in Crete, and thereby of our dominant images of ancient Minoan society. For as his half-sister Joan comments appositely: 'He was a romantic who needed escape from the present.' She further states, that by 1904 : 'He had set out to find a script; he had found four and could read none of them. But Time and Chance had made him the discoverer of a new civilization, and he had to make it intelligible to other men. Fortunately it was exactly to his taste: set in beautiful Mediterranean country, aristocratic and humane in feeling; creating an art brilliant in colour and unique in form. . It provided him with enigmas to solve and oracles to interpret, and opened a new world for eye and mind to dwell in; a world which seemed to isolate him from a world in which he had found no place' (Evans, 1943, 173, 350). (PL. IVa).

Evans's revitalization of a wondrous world of peaceful prosperity, stable divine autocrats and a benevolent aristocracy, owes a great deal to the general political, social and emotional 'Angst' in Europe of his time. He succeeded brilliantly in conjuring up both a physical and imaginative world of the lost civilization that dominates our vision of the Minoans even today. Hogarth complained that, 'Restorations like the Throne Room are not a question of methods, but of the gratifying of a desire to reconstruct tangibly what must otherwise only be imagined' (letter to Evans, reproduced in Cottrell, I96I, I37), and Leonard Cottrell adds with insight: 'But physical restoration of the walls, floors, columns and porticoes, satisfied only a part of Evans's nature. It was more difficult, and therefore more attractive, to discuss the moral and spiritual basis of the Minoan civilization' (idem, 154). Even in the authoritative Palace of Minos, Vol. 3, Evans permits himself the famous incantation to that lost wonderworld, in his vision on the Grand Staircase :

'It revives as no other part of the building, the remote past. It was indeed, my own lot to experience its strange power of imaginative suggestion, even at a time when the work of reconstitution had not attained its present completeness. During an attack of fever. . . and tempted in the warm moonlight to look down the staircase well, the whole place seemed to awake awhile to life and movement. Such was the force of the illusion that the Priest King with his plumed crown, great ladies, tightly girdled, flounced and corseted, long-stoled priests, and after them a retinue of elegant and sinewy youths-as if the Cup-Bearer and his fellows had stepped down from the walls-passed and repassed on the flights below' (Evans, III, 301 ). 
In the same vein there is the merging by Pendlebury of that vision of the ancient Minoan paradise with his own escapist, rustic paradise of early modern Crete, seen for example in his delightful identification of the Minoan 'stock' in present-day Cretans: 'Many a village boy might be the direct descendant of the Cup-Bearer of the Priest-King, and who can deny the possibility that he may be? Minoan too, is the sense of style which your modern Cretan has above all other Greeks' (Pendlebury, 197 I , 267). And read his commentary on the representation of the so-called 'Great Mother Goddess and her boy-god son': 'He is one of those soulless, fawn-like, heartless boys whom you meet in the wilder parts of Crete today' (idem, 273).

Evans saw the Minoans as the source of all future Greek civilization, ignoring any original Mycenaean contribution: 'Can it be doubted that the artistic genius of the later Hellenes was largely the outcome of that inherent in the earlier race in which they had been merged?' (Evans, 1912, 278). The Mycenaeans were 'only a provincial variant' (op. cit., 282), 'a mainland plantation' of the Minoan (op. cit., 281), and even the Homeric myths were revamped Minoan tales (op. cit., 288). Wace however replied that 'the Minoan domination over the Mainland has been grossly overestimated. It has' been pointed out that if we lacked all historical documents we should, if we used similar arguments, maintain that there was an Athenian domination of Etruria in later days' (cf. Pendlebury, 1971, 229). Worse was to come, with the suggestion that the Mycenaeans had taken over the Minoan civilization in the period of its height-i.e. concurrent with the Palace Style, which Evans described as 'the magnificent style of vase-painting prevalent at Knossos in the great days of the Palace' (cf. Evans, I90I, 51), but which good Minoanists are now quick to interpret as degenerate.

The rude assaults of the Mycenaeanists, so it seemed to Evans, seemed to parallel the same postulated attack of their Mycenaeans on his island paradise, and both he vigorously resisted. To this day a resistance movement fights alongside the ancient Minoans: if Mycenaeans came by LMII, their styles are degenerate, their achievements of little note-but to many even this admission is insupportable. And clearly if anything praiseworthy is to be attributed to the Mycenaean civilization as a whole, a Minoanist will look, as Evans did, to the Minoan source for the whole process-just as Peter Warren has done (1977).
The picture of the Minoan palace civilization as one of happy social equilibrium with lords and peasants all cheerfully occupying their respective places (PL. IVb), is neatly brought out in this heart-warming vision of Gerald Cadogan's on the Minoan elite: 'The inhabitants of the country houses will have helped social cohesion by taking certain responsibilities from the peasants and mediating between them and the central authorities' (Cadogan 1971). Likewise Paul Halstead (198I) offers us a Minoan Welfare State, with the palaces as regional centres of Supplementary Benefits and Spiritual Healing.

Before the palaces, we have the even happier vision of completely egalitarian communities of the Early Minoan and neolithic periods. Todd Whitelaw $(1983)$ hovers in his acceptance of such a society for the pre-palatial era. Bintliff's (1977) study of Minoan social change also envisaged an early egalitarian society of hamlets scattered over the Cretan landscape, united by the Palace Period under a centralized theocracy. This integration was achieved through the medium of a national cult, whose creation was marked by the establishment of a hierarchy of peak sanctuaries and ceremonial centres (Bintliff, r977a, Pt. I ch. 7, Pt. II ch. 8; 1977b; Blackman and Branigan, 1977).

It may seem surprising that this romantic and idealistic vision of an innocent, strifeless, fair society, survived to form a controlling model for my generation, but we have to recall the r 960 s rejection of the Materialist, Consumer ethos of the r 950 s, symbolized by Flower Power and the fascination with alternative worlds such as Eastern Mysticism, the Commune, Pot, and Lewis Binford. The collapse of this I 960 s to early ' 70 os renewed optimism in the perfectability or regeneration of modern society, is reflected in the surge of archaeological research from the 1970 s into the origins of inequality, the rise of elites and modes of coercion, the 'punch behind the priest' and so on. There has been, as Bob Chapman recently commented (1979), an unnoticed shift in the most recent archaeological theory towards a Materialist Marxist concern with stages of human evolution characterized by their individual modes of exploitation.

One of the first major blows to the rosyspectacled archaeologist came, in fact, with a reinterpretation of the Maya civilization, a mysterious and complex culture once flourishing in the tropical rain forests of Central America. Here great temples towering above numerous other important 
buildings within ceremonial centres, had long been seen as the residences of a priestly elite, who provided religious integration for a dense surrounding rural peasantry, in return for a tithe-another theocracy. By the I 970 os however the decipherment of the Maya glyphs and close study of wall paintings, together with a contemporary shift in cultural ethos for the archaeologists, led to a new image for the Maya-one of ruthless, regional elites, preoccupied with dynastic succession and the liquidation of their neighbours. Study of burials suggested that the elites were well-nourished up till the catastrophic collapse of the civilization, while peasants became increasingly undernourished and diseased (cf. Coe, 1962; I966; McAdams, 1972, with Culbert, 1973). Likewise, Bob Adams's classic 1960s survey of the rise of Mesopotamian civilization, with a key role being assigned to the temple ideology and economy, and communal consensus, has yielded in the 1970 s to a pronounced stress among Mesopotamian theorists on the rise of classes, social strife, and minority economic privileges, a scenario in which the temples now serve as a convenient ideological cover for these shifts of power and privilege (cf. McAdams, 1965; 1972, with Fried, 1978).

In prehistoric Europe and the Aegean, Colin Renfrew has led the vanguard of antisentimentalists, producing 'Big Men' and Chieftains everywhere in European prehistory-egocentric, pushy individuals stirring up the sluggish peasants towards civilization. At his extreme, for example in his recent Orkney volume, the possible religious significance of megalithic tombs and stone circles is ignored in favour of seeing these as markers for competitive territorial groups and prestige monuments for chieftains-despite the ironic parallel Renfrew draws with the medieval cathedral of St Magnus in the centre of the island group (Renfrew, 1979).

In Minoan archaeology we can surely detect the same hints of an ensuing collapse of that primitive paradise. The new stress on the blood lust and sacrifice elements in the bull-leaping activity (Pinsent, 1983 ) is in contrast to the generally cheery interpretation reflected in PL. III $a$. Then there are the dark inferences being drawn from Peter Warren's Late Minoan cannibalism (Warren, 1981), and the great fuss that is being created by the claims for dirty deeds at Arkhanes (Sakellarakis \& Sapouna-Sakellaraki, 198r). Before long we shall have, I suspect, many further instances of skulldug- gery raised. It is perhaps appropriate for us to pause awhile before the floodgates burst and note how much of this could have been, and sometimes was, anticipated long ago.

Evans, for example, on the bull cult, compared it with that nasty Mediterranean tradition of the amphitheatre and bull-ring: 'It may well be that, long before the days when enslaved barbarians were "butchered to make a Roman holiday", captives, perhaps of gentle blood, shared the same fate within sight of the "House of Minos"' (Evans, I901, 95-6). Likewise, our ethnographic and historical knowledge should have long ago led us to question whether any farming society can exist for thousands of years, as the Cretan Neolithic did, with the accompanying rise of communities as large as Knossos, without internal social differentiation; and whether that social division, continuing via I, 000 years of Early Bronze Age into the clearly stratified Palace society of almost a further 1,000 years life, could be plausibly maintained by communal consensus or involved a significant degree of conflict, suppression and exploitation. The Haghia Triadha Chieftain Cup, with its captain and troops, need not illustrate 'toy' soldiers. The Knossos faience plaques and miniature fresco fragments of Middle Minoan date, showing house and shrine façades, are a further object-lesson in controlling models. Sinclair Hood repeats the sound case that the former are part of a Siege-Mosaic (Hood, 1971, I 8 and P1. 22), but earlier writers were happier to see in it merely a 'Town Mosaic' (Hutchinson, 1962,173 ). More remarkable is the interpretation of the miniature fresco scene, as a 'fête champêtre'. Hutchinson writes unabashed: 'another fragment. . . shows an enthusiastic group of men waving spears . . . not, I think, in any hostile gesture, but rather, as Pendlebury remarks "like a cheering football crowd"' (idem, 181 ). These peaceable interpretations are the preferred popular reconstructions (PL. IIIb).

Furthermore, I suspect that when we have begun to recover a realistic fraction of the Cretan neolithic settlement pattern, and its burials, and when the Early Minoan larger sites are better understood and the accompanying burials analysed for status distinctions, we shall find ourselves in a stronglystratified society well before the end of the Neolithic. This will include the suggestion of individual and group conflict, and will be linked in with a new approach to the Minoans, who as a whole will now be studied into the foreseeable future in terms of 
landlords and tenants, the haves and the have-nots (perhaps with dietary studies in support), rather than with the old view of a perfect but increasingly hierarchical society. Again, I will repeat the point that the data may already be partially available for such revaluation, thinking for instance of the variation in gifts in Early Minoan burials, or the implication of seals and signets for Early Minoan private property.

What this article is suggesting, in effect, is that a dominant dialectic exists between shifts in contemporary philosophies and world views, and the changing interpretations of the archaeological record. Certainly new finds make it difficult to avoid reinterpretations, but overall I suspect that a more important factor is the outlook of the archaeologist on his own world, subsequently reflected in the messages of reinforcement he seeks and claims to recover from the world of the Past.

\section{BIBLIOGRAPHY}

BINFORD, L. R. 1968. Archaeological perspectives, in (eds) S. R. $\&$ L. R. Binford, New perspectives in archaealogy, 5-32 (Chicago).

BINTLIFF, I. L. I977a. Natural environment and human settlement in prehistoric Greece, BAR Suppl. Ser., 28 (Oxford).

r 977 b. New approaches to human geography, in (ed.) F.W. Carter, An historical geography of the Balkans, 59-II4 (London).

BLACKMAN, D. \& K. BRANIGAN. I977. An archaeological survey, $B S A$, LXXII, 13-84.

CADOGAN, G. 197x. Was there a Minoan landed gentry?, Institute of Classical Studies, Mycenaean Seminar, London, 19 May I97I, printed abstract.

1976. Palaces of Minoan Crete (London).

Chapman, R. w. 1979. Comments, $47^{-8}$, on $\mathrm{P}$ van de Velde, Social anthropology of a neolithic cemetery, Current Anthropology, $\mathrm{xx}, 37^{-5} 5^{8}$.

COE, M. D. 1962. Mexico (London).

1966. The Maya (New York).

COTTRELL, L. I961. The Bull of Minos (London).

Cllbert, T. P. (ed.). 1973. The Classic Maya collapse (Albuquerque).

evans, A. I901. The Palace of Knossos, BSA, vil, I-120.

1912. The Minoan and Mycenaean element in Hellenic life, YHS, xxxi, 277-97.

1921-30. The Palace of Minos at Knossos (London).

EvaNS, J. 1943. Time and chance (London).

FRIED, M. H. 1978. The State, the chicken and the egg, in (eds) R. Cohen \& E. R. Service, Origins of the State (Philadelphia).

GatherCole, P. 1971. Patterns in prehistory: an examination of the later thinking of V. Gordon Childe, World Archaeology, III, 225-32.

HALSTEAD, P. I98I. From determinism to uncertainty: social storage and the rise of the Minoan Palace, in (eds) A.
Sheridan \& G. Bailey, Economic archaeology, I87-213, BAR, Int. Ser. 96 (Oxford). HAWkES, J. 1981. A quest for love (London). Hood, s. 1971. The Minoans (London). hutchinson, R. w. xg6z. Prehistoric Crete (London). MC. C. ADAMS, R. I965. The evolution of urban society (Chicago).

1972. Some hypotheses of the development of early civilisations, reprinted in (ed.) M. P. Leone, Contemporam archaeology, 359-64 (Evansville).

PENDLEBLRY, J. D. S. 1971 (1939). The archaeology of Crete: an introduction (London).

PINSENT, J. 1983. Bull-leaping, in (eds) O. Krzyszkowska \& L. Nixon, Minoan Society, Procs. Cambridge Colloquium 1981 (Bristol).

PLCMB, J. H. I97I. Introduction to Greek Society by A. Andrewes (London).

RALLing, C. I980. What is television doing to history?, The Listener, 10 Jan. 1980 .

RENFREW, C. I979. Investigations in Orkney (London).

SAKELlarakis, Y, E. SAPOCNA-SAKellaraki, 198r. Drama of death in a Minoan Temple, National Geographic, Feb. 1981 , $205^{-23}$.

Warren, P. 1977. The emergence of Mycenaean Palace civilisation, in (ed.) J. Bintliff, Mycenaean geography, 68-75 (Cambridge).

I981. Knossos: Stratigraphical Museum Excavations, 1978 80, Pt. I, Archaeological Reports for 1980-81, Society for Hellenic Studies (London), 73-92.

Whitelaw, т. M. 1983. The settlement at Fournou Korifi, Myrtos, and aspects of Early Minoan social organization, in (eds) O. Krzyszkowska \& L. Nixon, Minoan Society, Procs. Cambridge Colloquium 1981 (Bristol).

WILLS, H. I979. Pillboxes: a study of UK defences 1940-4I, Current Archaeology, vi, 10, 304-6. 



PLATE IV: STRUCTURALISM AND MYTH IN MINOAN STUDIES

(a) From 'The Ancient World', p. 48, by R. Ogilvie. (b) From 'Looking at Ancient History', p. 49, by R. F. Unstead 